\title{
Trigonalidae (Hymenoptera) of Thailand, other southeastern Asian records, and a new Trigonalys from India
}

\author{
David R. Smith', Pierre Tripotin ${ }^{2}$ \\ I Research Associate, Department of Entomology, National Museum of Natural History, Smithsonian Insti- \\ tution, P.O. Box 37012, MRC 168, Washington, DC 20013-7012 210 Crowther Street, Whitfield Cairns, \\ Queensland 4870, Australia
}

Corresponding author: David R. Smith (sawfly2@aol.com)

Academic editor: W. Pulawski Received 13 January 2015 | Accepted 28 January 2015 | Published 11 June 2015

http://zoobank.org/9B744E78-579D-46BA-B4D6-CC8108E699E4

Citation: Smith DR, Tripotin P (2015) Trigonalidae (Hymenoptera) of Thailand, other southeastern Asian records, and a new Trigonalys from India. Journal of Hymenoptera Research 44: 1-18. doi: 10.3897/JHR.44.4495

\begin{abstract}
Seven species of Trigonalidae are recorded from Thailand, Lycogaster flavonigrata Chen, Achterberg, $\mathrm{He}$ \& Xu, L. rufiventris (Magretti), Taeniogonalos fasciata (Strand), T. gestroi (Schulz), T. sauteri Bischoff, T. tricolor Chen, and an unidentified species. Four species, L. flavonigrata, T. cordada Chen, Achterberg, $\mathrm{He}$ $\& \mathrm{Xu}$, T. sauteri, and T. tricolor are newly recorded from Laos. Diagnoses, illustrations, and distribution records are given for the Thailand species. Trigonalys india Smith, sp. n., is described from southern India for specimens previously misidentified as T. rufiventris.
\end{abstract}

\section{Keywords}

Trigonalid wasps, Lycogaster, Pseudogonalos, Taeniogonalos, Trigonalys

\section{Introduction}

Trigonalidae is a small, worldwide family with the greatest diversity in the tropical regions. However, there are few records from southeastern Asia, most of which are recorded in Carmean and Kimsey (1998) and Chen et al. (2014). Previously, only two species were known from Thailand, T. gestroi (Schulz, 1908) (as Taeniogonalos thwaitesii (Westwood, 1874)) and T. tricolor Chen, 1949, and only one species from Laos, T. gestroi. Here, 
we record seven species from Thailand and five species from Laos, provide records of other species examined from southeastern Asia, describe the previously unknown male of Lycogaster rufiventris (Magretti, 1897), and describe a new species of Trigonalys from India which had been misidentified as $L$. rufiventris.

\section{Materials and methods}

The basis and focus for this study are the collections made by the Thailand Biodiversity Inventory, a collaborative project initiated by M. J. Sharkey, University of Kentucky, Lexington, and the Queen Sirikit Botanical Garden and National Parks, Wildlife, and Plant Conservation Department of Thailand. These collections included two species of Lycogaster and four species of Taeniogonalos. The collections from Laos are from the Oberösterreichische Landes Museen Linz, Linz, Austria. A few additional records are from other collections listed below.

Museum acronyms are as follows: Canadian National Collection of Insects, Ottawa, Canada (CNC); Oberösterreichische Landes Museen Linz, Linz, Austria (OLML); Museum of Comparative Zoology, Harvard University, Cambridge, MA, USA (MCZ); Oregon State Arthropod Collection, Department of Zoology, Oregon State University, Corvallis, OR, USA (OSAC); Oxford University Museum of Natural History, Oxford, UK (OXUM); Queen Sirikit Botanical Garden Entomological Collection, Chiang Mai, Thailand (QSBG); National Museum of Natural History, Smithsonian Institution, Washington, D.C., USA (USNM); and the collection of Pierre Tripotin, Whitfield Cairns, Australia (PT).

Images were obtained using an EntoVision Imaging Suite that included a firewire JVC KY-75 3CCD digital camera mounted to a Leica M16 zoom lens via a Leica z-step microscope stand. Multiple focal planes were merged using Cartograph 5.6.0 (Microvision Instruments, France) software.

Locality data are given essentially as they appear on the specimen labels. Complete synonymies, except $L$. rufiventris, are found in Chen et al. (2014). A key to genera, descriptions and illustrations of all species, except $L$. rufiventris, and synonymies are given in the treatment of the Trigonalidae of China (Chen et al. 2014).

\section{Results}

\section{Lycogaster flavonigrata Chen, Achterberg, He \& Xu}

Figs 1-3

Lycogaster flavonigrata Chen, Achterberg, He \& Xu, 2014: 49, figs 119-129.

Diagnosis. Female. Length $10.5 \mathrm{~mm}$. Antenna, head, and mesosoma black. Legs black with trochanters and small spot at base of each tibia white. Metasoma black; tergite 2 

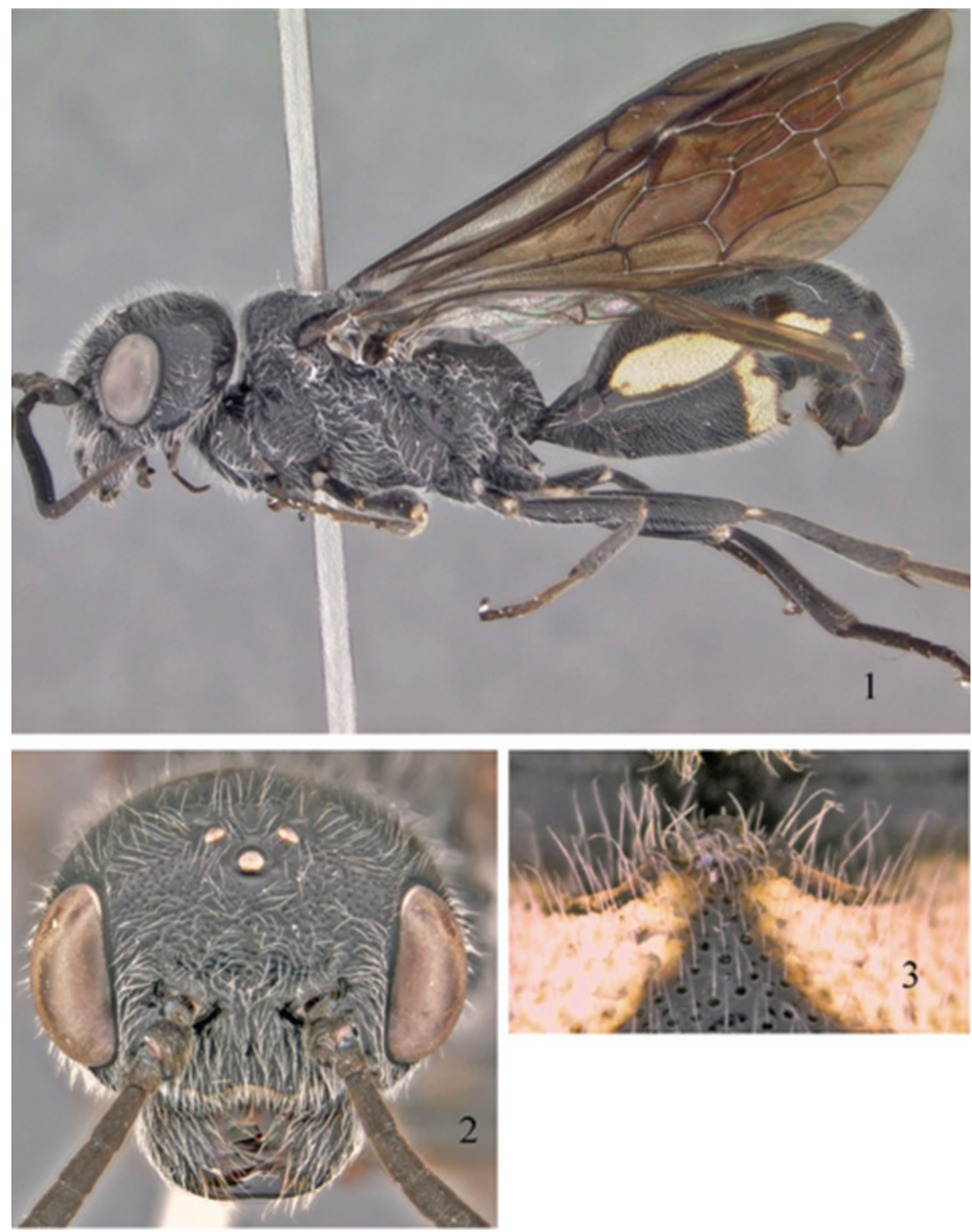

Figures I-3. Lycogaster flavonigrata, female. I Lateral. 2 Head, front 3 Apex of second sternite, ventral.

with lateral longitudinal white stripe; tergite 3 with lateral oval white spot; tergite 4 with small lateral white spot, much smaller than that on tergite 3 ; sternite 2 with apical yellow transverse narrow band. Wings darkly infuscate; lighter toward base; veins and stigma black. Antenna short, flagellum slightly incrassated at center. Medio-apical process present on sternite 2 , slightly concave at center. 
Male. Unknown.

Specimens examined. LAOS: Prov. Hua Phan, Phou Pan, Umg. Ort Ban Saleui, $20^{\circ} 13^{\prime} 30^{\prime \prime N} / 103^{\circ} 59^{\prime} 26 " \mathrm{E}, 1350-1900 \mathrm{~m}, 01.05 .2012$, KJa, leg. C. Holzschuh \& locals (1 9 , OLML), same but 22.04.2012 (1 9 , OLML); N, 24.IV-16.V.1999, Louang Phrabang Prov., 20³3-4'N, 102¹4'E, Ban Song Cha (5 km W), \pm 1200 m, Vít Kubáň leg (1 9 OLML); Khammouan prov., 250 m, Ban Khoun Ngeun, N1807', E104²9', E. Jendke leg. ( 1 , OLML). THAILAND: Phetchabun, Nam Nao NP Check point, $16^{\circ} 43.695^{\prime} \mathrm{N}, 101^{\circ} 33.797^{\prime} \mathrm{E}, 921 \mathrm{~m}$, Malaise trap, 28.iv-5.v.2007, Leng Jantaeb leg., T2654 (1 , QSBG).

Distribution. This species was described from China (Fujian, Jiangxi, Yunnan) (Chen et al. 2014). These are the first records from Laos and Thailand.

Comments. The almost completely black color with some yellow markings on the metasoma and the dark wings help distinguish this species.

Lycogaster are fairly rare in collections. From observations by PT, a good number of species of Asian Lycogaster seem to parasitize the Eumeninae through caterpillars, somewhat like Bareogonalos. At least in Korea this explains their scarcity in collections. They are almost never found in traps set in forest but seem to research more sunny habitats where potter wasps nest, and therefore are likely to have a much better resistance to desiccation than the other Trigonalids.

\section{Lycogaster rufiventris (Magretti)}

Figs 4-7

Trigonalys rufiventris Magretti 1897: 311, figs 2, 3; Carmean and Kimsey 1998: 70. Lycogaster rufiventris: Schulz 1908: 28, fig. 2; Bischoff 1938: 10; Weinstein and Austin 1991: 428; Chen et al. 2014: 45.

Diagnosis. Female: Length, 8.0-10.0 mm. Antenna black. Head black with clypeus except for black narrow anterior margin and mandible except black apex white. Mesosoma black with anterior margin of pronotum, spot on posterior lateral corners (near tegula) of pronotum, tegula, small oval spot on posterior-central prescutum, oval spot on anterocentral area of mesoscutellum, and metascutellum white. Legs black with most of trochanters except ventrally, extreme tip at base and apex of femora, outer surface of fore tibia, foretarsus, and extreme bases of mid- and hind tibiae white. Metasoma orange with tergite 5 or 6 to apex, and sterna 3 to apex black; apical broad margin of sternite 2 white. Wings lightly infuscated, a little darker toward apex; veins and stigma black. Head: Antenna with 24-25 antennomeres; flagellum somewhat incrassate at center. Shiny; vertex almost without punctures; frons more densely punctate; covered with fine white hairs. Mesosoma: Shiny, uniformly densely punctate; covered with fine white hairs. Metasoma: Shiny, uniformly densely punctate; covered with fine white hairs. Medio-apical process with small indentation at center on sternite 2 (Figs 4, 6). 

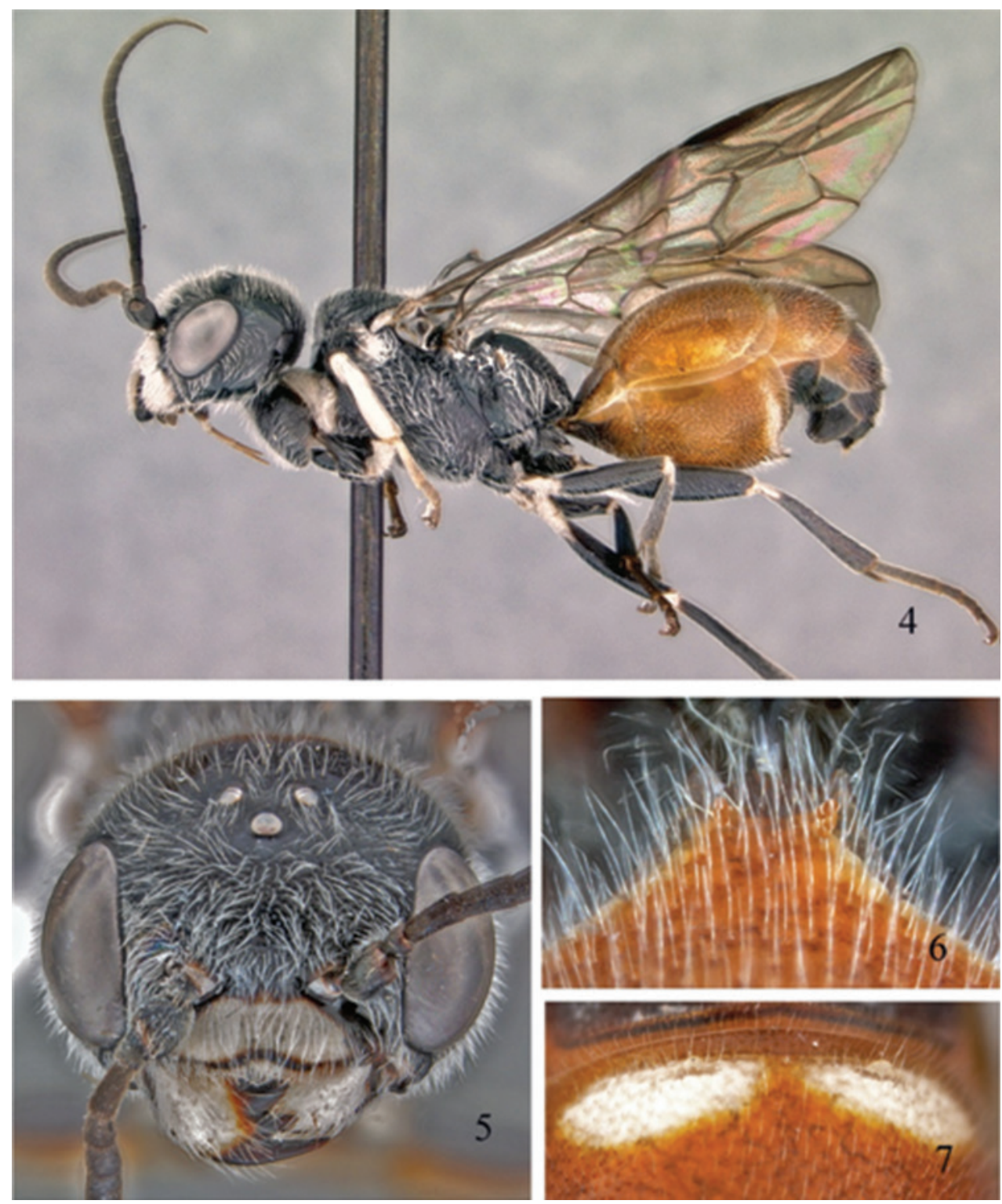

Figures 4-7. Lycogaster rufiventris. 4 Lateral, female 5 Head, front, female 6 Apex of second sternite of female, ventral $\mathbf{7}$ Apex of second sternite of male showing paired protuberances.

Male: Length 8.0-9.0 mm. Color similar to female. Antenna without tyloids. Paired protuberances at center near apex of $2^{\text {nd }}$ sternite (Fig. 7).

Specimens examined. THAILAND: Prachuab Khiri, Khan, Khao Sam Roi Yot NP, Sailine wetland/Pa Gwad/N, 129.2'N, 9958.298'E, Malaise trap, 1-8.ii.2009, Yai; Amnad leg., T4191 (1 $\mathrm{O}$, QSBG)); Prachaub Khiri, Khan, Khao Sam Yot NP, Saline wetland/Pa Gwad/N, $12.153^{\circ} \mathrm{N}, 99.972^{\circ} \mathrm{E}, \mathrm{MT}, 18-26 . \mathrm{i} .2009$, Yai; Amnad, H2648 (1 
+, QSBG); Lampang, Chae Son NP, behind youth camp, $18.831^{\circ} \mathrm{N}, 99.458^{\circ} \mathrm{E}, 445$ m, MT, 14-21.ii.2008, B. Kwannui \& A. Sukpeng, H2572 (1 ð’, USNM); Loei, Phu Kradueng NP, Mixed deciduous/S Na Noy office, $16.817^{\circ} \mathrm{N}, 101.794^{\circ} \mathrm{E}, 276 \mathrm{~m}, \mathrm{MT}$, 7-14.v.2008, Thonghuay Phatai, H2611 (1 +, USNM); Sakon Nakhon, Phu Phan NP, stream entrance of Nam Pung substation, $16^{\circ} 54.63^{\prime} \mathrm{N}, 103^{\circ} 54.266^{\prime} \mathrm{E}, 281 \mathrm{~m}$, Malaise trap, 6-12.v.2007, Sailom Tongboonchai leg., T2611 (1 \&, QSBG); Nakhon Si Thammarat, Namtok Yong NP, Behind campground lavatory, $8^{\circ} 10.434^{\prime} \mathrm{N}, 99^{\circ} 44.508^{\prime} \mathrm{E}, 80$ m, Malaise trap, 23-29.vii.2008, U.prai.K. leg, T3082 (1 , PT).

Distribution. Myanmar; Thailand.

Comments. The contrasting red metasoma is not known in any other species of Lycogaster. Magretti (1897) described this species from Myanmar. The species was assigned to Lycogster by Schultz (1908), Bischoff (1938), and Weinstein and Austin (1991). Carmean and Kimsey (1998) could not locate the holotype and placed it in Trigonalys based on similarly colored specimens from central and southern India. We have examined those specimens from India, borrowed from the MCZ and OSAC, and confirm that they are a species Trigonalys. However, as explained by Schultz (1908), who redescribed the species from the holotype and corrected the sex to a female, and Chen et al. (2014), Magretti's species is clearly a Lycogaster. Our specimens from Thailand agree with Magretti's description of rufiventris, and confirm placement in Lycogaster. The discovery of the male further confirms placement in Lycogaster. The absence of tyloids on the antenna and presence of a pair of protuberances centrally near the apex of sternite 2 (Fig. 7) is typical for the genus. This is the first collection of both sexes of this species since the original description.

\section{Pseudogonalos hahnii (Spinola)}

Trigonalys hahnii Spinola 1840: 1 .

Specimen examined. CHINA: Yunnan Prov., Lijiang, 1.-19.7.1992, Heishui $35 \mathrm{~km}$ $\mathrm{N}$ of, 27.13N, 100.19E, lgt. S. Becvar (1 9 , OLML).

Comments. This is a widespread Palearctic species and is characterized and illustrated by Chen et al. (2014), who recorded it from a number of Chinese provinces. This specimen is the first record from Yunnan.

\section{Taebiogonalos cordata Chen, Achterberg, He \& Xu}

Taeniogonalos cordata Chen, Achterberg, He \& Xu, 2014: 140, figs 317-327.

Diagnosis. Vertex of head black, without V-shaped pale pattern posteriorly; middle mesonotal lobe yellow laterally and orange brown medially, strongly contrasting with black lateral lobes; anterior half of forewing dark brown; mesoscutellum largely or- 
ange brown, black only medio-poseriorly and narrowly black laterally; female without medio-apical process on sternite 2 .

Specimen examined. LAOS: Prov. Hua Phan, Phou Pan, Umg. Ort. Ban Saleui, $20^{\circ} 18^{\prime} 30^{\prime \prime N}, 103^{\circ} 59^{\prime} 26^{\prime} \mathrm{E}, 1350-1900$ m, 19.04.2012, KJa, leg. C. Holzschuh \& locals ( 1 , OLML).

Comments. This species was described from China (Yunnan), and this specimen from Laos is identical to the description. It is the first record from Laos.

\section{Taeniogonalos fasciata (Strand)}

Figs 8-10

Poecilogonalos fasciatus Strand, 1913: 97.

Diagnosis. Female, length, $8.5 \mathrm{~mm}$. Antenna black with basal antennomeres reddish. Head black with inner and outer orbits, antennal tubercles, clypeus, and mandible black. Mesosoma mostly red with sterna black. Legs black and white, trochanters, fore tibia and tarsus, and bases of mid- and hind tibiae white. Metasoma black with broad apical bands on basal two tergites. Wings hyaline with black dorso-apical spot covering most of radial cell. Second sternite without medio-apical projection. Male similar to female.

Specimen examined. CHINA: Huan pr., $30 \mathrm{~km} \mathrm{~N}$. Yanjiajie from Cayong, 29.5.2005, Ivo Janis lg. (1 o, OLML); Sichuan, Shangliang, 14.5-26.5.2005, lg: E. Kucera (1 + , OLML). THAILAND: Mae Hong Son, Namtok Mae Surin NP, Visitor's center, $19^{\circ} 21.593^{\prime} \mathrm{N}, 97^{\circ} 59.245^{\prime} \mathrm{E}, 228 \mathrm{~m}$, Malaise trap, 19-26.viii.2007, Manu Namadkum leg., T5872 (1 q, QSBG).

Distribution. China, Indonesia, Iran, Japan, Korea, Malaysia, Russia (Primorskii Krai); Taiwan, Thailand. Chen et al. (2014) recorded Japan, Korea, Taiwan, Russia, and 13 provinces in China. Indonesia, Iran, and Malaysia were recorded by Carmean and Kimsey (1998) and may need confirmation.

Comments. This is the only species with a mostly red mesosoma. It is a widespread species in eastern Asia. It is one of the more common species of Trigonalidae in Korea, Japan, and parts of China but seems to be rare in southeastern Asia.

\section{Taeniogonalos gestroi (Schulz)}

Figs 11-13

Poecilogonalos pulchella gestroi Schulz 1908: 24, fig. 1.

Taeniogonalos gestroi: Chen et al. 2014: 141 (complete synonymy given).

Diagnosis. Female, Length, mm. Ground color yellow with black maculae, pattern similar to Figs 11-13. Wings hyaline; forewing with black dorso-apical spot covering most of radial cell. Second sternite without medio-apical process. Male similar to female. 

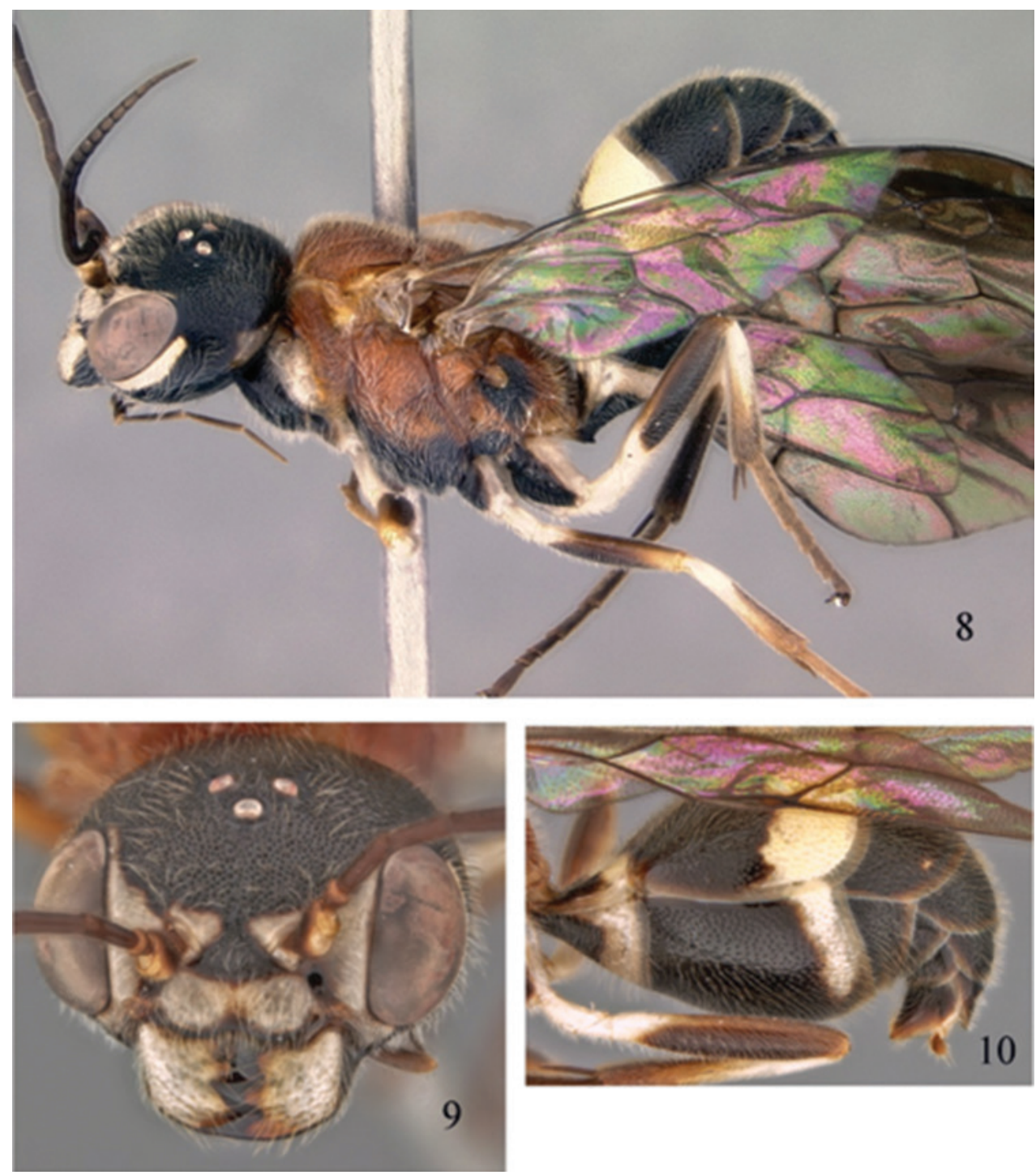

Figures 8-10. Taeniogonalos fasciata, female. 8 Lateral 9 Head, front 10 Metasoma, lateral.

Specimens examined. INDIA: NE, Assam, 26 45W, $93^{\circ} \mathrm{N}$, Pan Bari Res. for, leg. Murzin, XI.97 (1 q, OLML). LAOS: south, Ban Houaykong, 18-30.4.99,O. Šauša lgt (1 9, OLML); south, Ban Itou env., 10-18.4.1999, O. Šauša lgt (1 , OLML); south, Pakse env., 18-30.4.1999, Spevar lgt (1 \&, OLML); C, 20-29.V.04, Khammouau pr., 250 m, Ban Khoun Ngeun, $18^{\circ} 07^{\prime} \mathrm{N}, 104^{\circ} 29^{\prime} \mathrm{E}$, Jendek \& Šauša lg (1 †, OLML). MALAYSIA: W. Perak, 25 km NE of IPOH, 1200 m, Banjaran Titi Wangsa Mts., KORBU Mt, 11-16.I.1999, P. Čechovský leg. (1 †, OLML); Perak, Cameron Highlands,Batu, 19.Vill env, 590 m, N 4²2', E 101²0', Pacholatko If., 05/09 (1 ㅇ, 

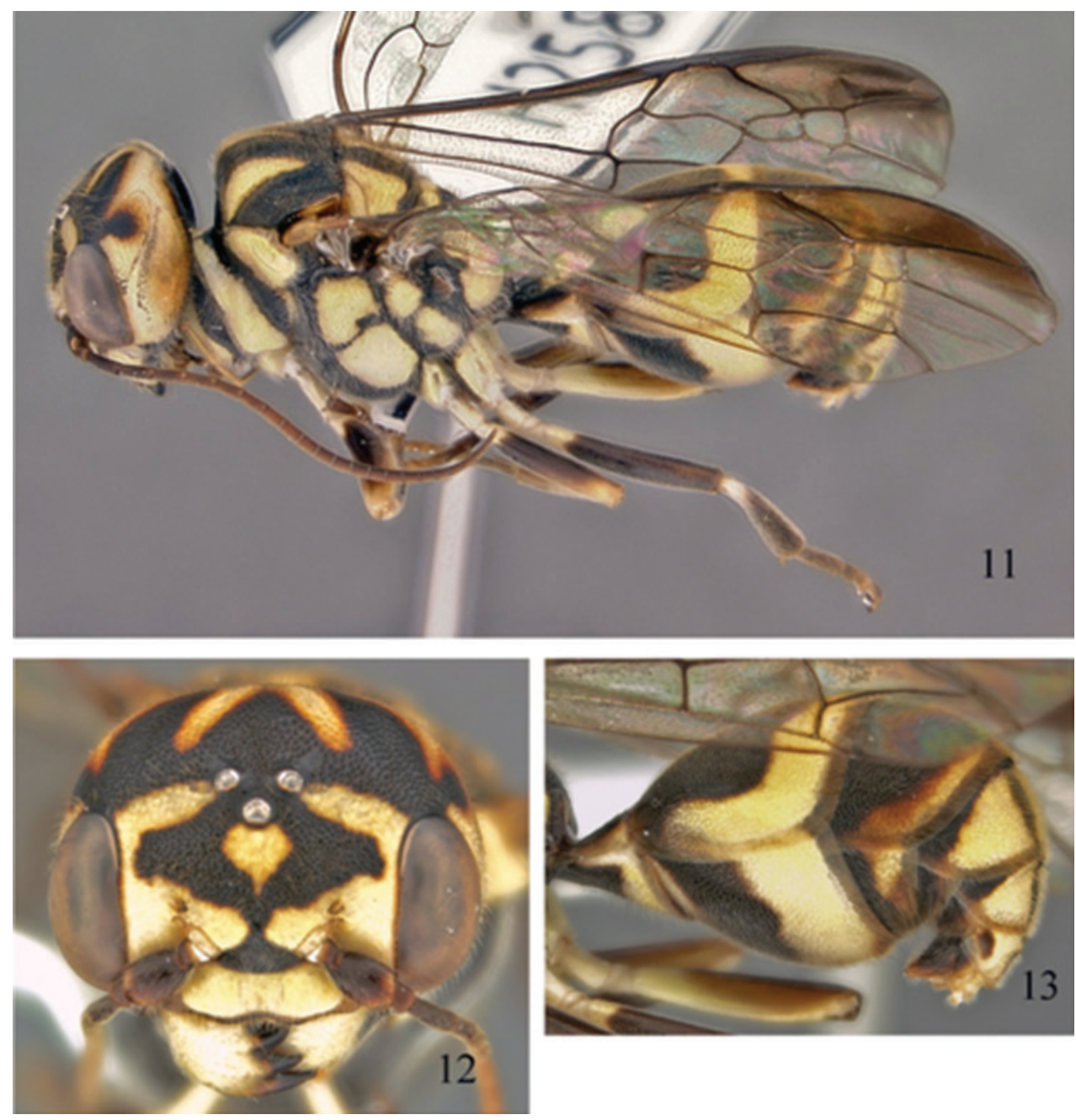

Figures I I-I3. Taeniogonalos gestroi, female. I I Lateral. I 2 Head, front 13 Metasoma, lateral.

OLML) ; Pahang, 30 km NE Raub, -300 m, Lata Lembik, IV-V.2002, ET, 356'N, $101^{\circ} 38^{\prime} E$, Jendek \& O. Šauša leg. (5 o, OLML). THAILAND: Sakon Nakhon, Phu Phan NP, Dry evergreen forest near house at 1567 station, $16.81^{\circ} \mathrm{N}, 103.892^{\circ} \mathrm{E}$, 512 m, MT, 9-16.xii.2006, S. Kongnara, H2642 (1 9, QSBG); Mae Hong Son, Namtok Mae Surin NP, E/Huai Fai Kor reservoir, $19^{\circ} 20.616^{\prime}$ N, 9759.300'E, Malaise trap, 18-25.v.2008, Kamkoon; A leg., T3518 (1 ㅇ, QSBG); Mae Hong Son, Namtok Mae Surin NP, Visitor's center, $19.36^{\circ} \mathrm{N}, 97.988^{\circ} \mathrm{E}, 228 \mathrm{~m}, \mathrm{MT}, 23-30$. iii.2008, Manu Namadkum, H2679 (1 \&, QSBG); Nakhon Si Thammarat, Namtok Yong NP, Behind campground lavatory, $8^{\circ} 10.434^{\prime} \mathrm{N}, 99^{\circ} 44.508^{\prime} \mathrm{E}, 95 \mathrm{~m}$, Malaise trap, 15-22.xii.2008, U-prai; K. leg., T4275 (1q, QSBG); Mae Hong Son, Nantok Mae Surin NP, Nature trail, $19.344^{\circ} \mathrm{N}, 97.988^{\circ} \mathrm{E}, 334 \mathrm{~m}, \mathrm{MT}, 15-22 . v i i .2007$, 
Jittrakorn Kaewmanee, H2578 (1 9 , QSBG); Phetchabun, Nam Nao NP Check point, $16^{\circ} 43.687^{\prime} \mathrm{N}, 101^{\circ} 33.754^{\prime} \mathrm{E}, 924 \mathrm{~m}$, Malaise trap, 19-26.v.2007, Noopean Hongyothi leg., T2662 (3 +, QSBG, USNM); Nakhon Si Thammarat, Namtok Yong $\mathrm{NP}$, behind campground lavatory, $8.174^{\circ} \mathrm{N}, 99.742^{\circ} \mathrm{E}, 95 \mathrm{~m}, \mathrm{MT}, 12-19.1 .2009$, Uprai; K., H2559 (1웅 QSBG); Chiang Mai, Doi Chiang Dao WS Pha Tang unit, $19^{\circ} 24.978^{\prime} \mathrm{N}, 98^{\circ} 54.886$ 'E, $526 \mathrm{~m}$, Malaise trap, 24-31.iii.2008, Songkran \& Apichart leg., T3161 (1 q, QSBG); Trang NP Khoa Chong Forest Research Stn., $7^{\circ} 33.033^{\prime} \mathrm{N}, 99^{\circ} 47.383^{\prime} \mathrm{E}, 74 \mathrm{~m}$, Malaise trap, 0.xi.2005, D. Lohman leg., T.6372 (1 + , QSBG); Chiang Mai, Doi Chiang Dao WS, Pha Tang unit, $19.416^{\circ} \mathrm{N}, 98.915^{\circ} \mathrm{E}$, 526 m, MT, 14-21.x.2007, Songkran \& Apichart, H2613 (1 q, QSBG); Chiang Mai, Queen Sirit Botanic Garden, $18.881^{\circ} \mathrm{N}, 98.862^{\circ} \mathrm{E}, 811 \mathrm{~m}, \mathrm{MT}, 23-30 . v i .2009$. K. Kaewjanta et al., H2624 (1 ${ }^{\lambda}$, QSBG); Chiang Mai, NP Queen Sirit Botanic Garden, $18^{\circ} 52.845^{\prime} \mathrm{N}, 98^{\circ} 51.705^{\prime} \mathrm{E}, 811 \mathrm{~m}$, Malaise trap, 26.v-2.vi.2009, Kaewjanta \& Sawkord leg., T6373 (1 9 , USNM); Chiang Mai, Queen Sirit Botanic Garden, $18.881^{\circ} \mathrm{N}, 98.862^{\circ} \mathrm{E}, 811 \mathrm{~m}, \mathrm{MT}, 19-26 . v .2009$, K. Kaewjanta \& R. Sawkord, H2595 (1 9 , PT); Petchaburi, Kaeng Krachan NP, Panernthung/ladies washroom, $12.797^{\circ} \mathrm{N}, 99.456^{\circ} \mathrm{E}, 970 \mathrm{~m}, \mathrm{MT}, 8-15 . v i i i .2008$, Sirichai \& Chusak, H2583 (1 , QSBG); Nakhon Si Thammarat, Namtok Yong NP, Behind campground lavatory, $8.174^{\circ} \mathrm{N}, 99.742^{\circ} \mathrm{E}, 95 \mathrm{~m}, \mathrm{MT}, 2-9$. iii.2009, U-prai; K., H2570 (1 + , USNM); Trang, Khoa Pu-Khoa Ya NP, 7³3.038'N, 9947.369'E, 75 m, Malaise trap, 16-19. vi.2006, M. Sharkey leg., T1954" (1 ㅇ, QSBG); Loei, Phu Ruea NP, Rong Huay Maklaow, $17.494^{\circ} \mathrm{N}, 101.35^{\circ} \mathrm{E}, 1167 \mathrm{~m}, \mathrm{MT}, 12-19 . v .2007$, Patikhom Tumtip, H2645 (1 9, QSBG); Chiang Dao, 19-21.V.1997, leg. M. Snizek (1 + , OLML); Prov. Mae HongSon, WNW Pai, Mo Paeng Wasserfall, Lichtfang, 11.04.2000, 900 m, 19²2'41"N/98 22'34"E (GPS), leg. H. \& R. Rausch, 03/2000 (1 ㅇ, OLML); bor. occ., Soppong (Pai), 28.v.-5.VII.1997, leg.M. Snizek (1 $q$, OLML); Trang Prov., near Nam tok Ton Prov, Khoa Chong Mt., 140 m, 7³2'15"N, 9947'36"E, iii.2005, D. Lohmai (1 9, CNC). Also recorded from Thaleban NP, $200 \mathrm{~m}$ (Chen et al. 2014).

Distribution. China (Hainan, Jiangsu, Yunnan), India, Indonesia, Malaysia, Myanmar, Laos, Papua New Guinea, Taiwan, Thailand (Chen et al. 2014). Chen et al. (2014) gave Sri Lanka, but this is probably not correct.

Comments. This was the most commonly collected species and can be distinguished by its yellow and black color pattern and the female lacking a medio-apical process on the second sternite. Chen et al. (2014) discussed the use of the name gestroi. This was commonly known as T. thwaitesii (Westwood), which was described from Sri Lanka and which Carmean and Kimsey (1998) believed to be a widespread, variable species in Asia. Examination of Westwood's type (OXUM) indicated that thwaitesii is different from specimens from southeastern Asia which were previously referred to as T. thwaitesii, confirming Schultz's (1908) conclusions. The name gestroi is thus available for the Asian populations. So far as we can tell, T. thwaitesii is confined to Sri Lanka and possibly southern India. Further studies are needed based on specimens from its entire range. 


\section{Taeniogonalos sauteri Bischoff}

Figs $14-16$

Taeniogonalos sauteri Bischoff 1913: 153.

Diagnosis. Female, length, $8.0 \mathrm{~mm}$. Black with yellow pattern similar to Figs 14-16. Head with yellow markings on occiput, gena, inner orbits, antennal tubercles, and clypeus. Mesosoma with yellow spots at anterior corners of middle lobe and spot on upper pronotum; meso and metascutellum orange. Legs black with hind coxa and bases of tibiae white. Metasoma black with broad apical yellow bands on first and second segments and lateral yellow spots on third to apical tergites. Short, blunt medio-apical process, truncate at apex, on sternite 2 (Figs 14, 16). Male similar to female except for sexual differences.

Specimens examined. LAOS: Hua Phan Prov., Ban Saleui; Phou Pan Mt., $20^{\circ} 13^{\prime} 30 " \mathrm{~N} / 103^{\circ} 59^{\prime} 26^{\prime} \mathrm{E}$ GPS, 1350-1900 m, 20.04.2010, leg. C. Holzschuh \& locals (1 9 , OLML), same but 14-18.04.2010 (1 9 , OLML); Prov. Hua Phan, Phou Pan, Umg. Ort Ban Saleui, 20¹3'30"N/ 10359'26"E, 1350-1900 m, 03.05.2012, KJa, leg. C. Holzschuh \& locals (1 9 , OLML), same but 19.04.2012 (1 9 , OLML). TAIWAN: Taoyoan Prov., Mingehih env., 1075 m, N24.65', E121.42 ${ }^{\circ}$, J. Halada, 9-5.2012 (1 O, OLML). TAIWAN: Taeyoan prov., Mingehih env., $1075 \mathrm{~m}$, N 24.65 , E 121.42 , J. Halada, 9.5.2012 (1 9 , OLML). THAILAND: Petchaburi, Kaeng Krachan NP, Panernthung/km27/water pump, $12^{\circ} 49.151^{\prime} \mathrm{N}, 99^{\circ} 22.483^{\prime} \mathrm{E}$, 950 m, Malaise trap, 11-18.vii.2008, Sirichai \& Chusak leg., T4334 (1 + , QSBG).

Distribution. China (Fujian, Guangxi, Hunan, Shandong, Zhejiang), Japan, Philippines, Taiwan (Chen et al. 2014). These are the first records for Laos and Thailand.

Comments. These specimens are identical to $T$. sauteri as characterized by Chen et al. (2014).

\section{Taeniogonalos tricolor Chen}

Figs 17-19

Poecilogonalos tricolor Chen 1949: 16.

Diagnosis. Female: Length $7.0 \mathrm{~mm}$. Reddish brown and black, with black maculae and color similar to Figs 17-19. Head mostly reddish brown with black on occiput and frons. Mesosoma reddish brown with black maculae on each lobe and most of pleurae and sterna black. Legs reddish brown to black. Metasoma black with broad reddish-brown apical bands on tergites. Metasomal sternite 2 without medio-apical process. Male: Similar to female.

Specimens examined. CHINA: Szechuen [Sichuan], Behluhdin, $6000 \mathrm{ft}$., VII.25-IX.1.1932, DCGraham (1 9 , USNM); Szechuen [Sichuan], ShinKaiSi, Mt. Omei, $4400 \mathrm{ft}$., 8.16-20.34, DCGraham (1 9 , USNM), same except without date (1 

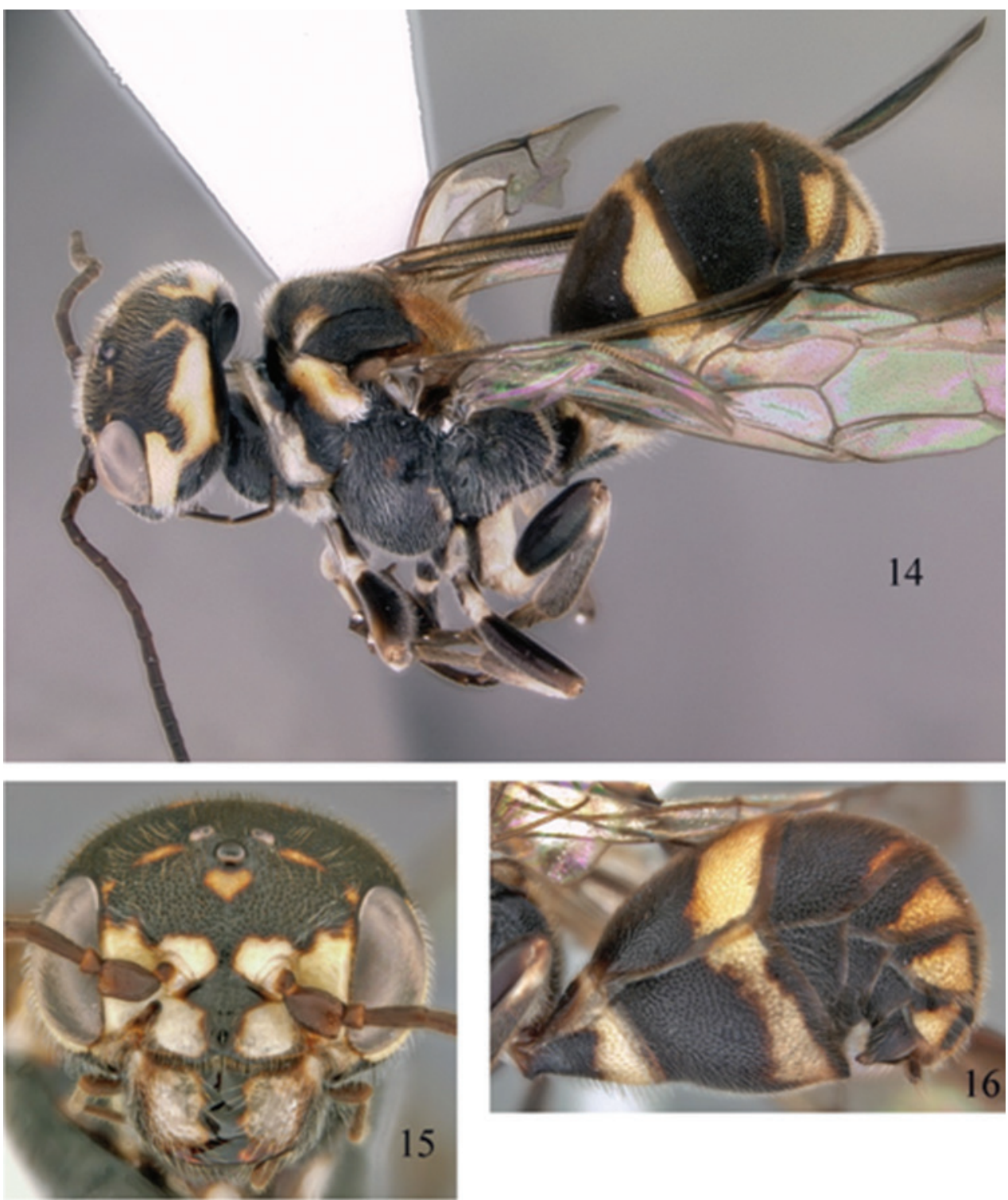

Figures I4-16. Taeniogonalos sauteri, female. I4 Lateral I5 Head, front 16 Metasoma, lateral.

ㅇ, USNM); Szechuen [Sichuan], O-Er26mi N Li Fan, 9000 ft., 1933, DCGraham (1 q, USNM). LAOS: Phongsaly pr., Phugsaly env., -1500 m, N2141', E10206', Pacholátko lg., 06/2008 (1 9 , OLML); Hua Phan Prov., Ban Saleui, Phou Pan- Mt., $20^{\circ} 13^{\prime} 30 " \mathrm{~N}, 103^{\circ} 59^{\prime} 26^{\prime} \mathrm{E}, 1350-1900 \mathrm{~m}, 07.05 .2011$, leg. C. Holzschuh + locals (1 O, OLML), same except 10.05.2001 (1 +, OLML), same except 10.04.2010 (1 , OLML). THAILAND: Chiangmai, 4-VI-52 (1 9 , USNM). 

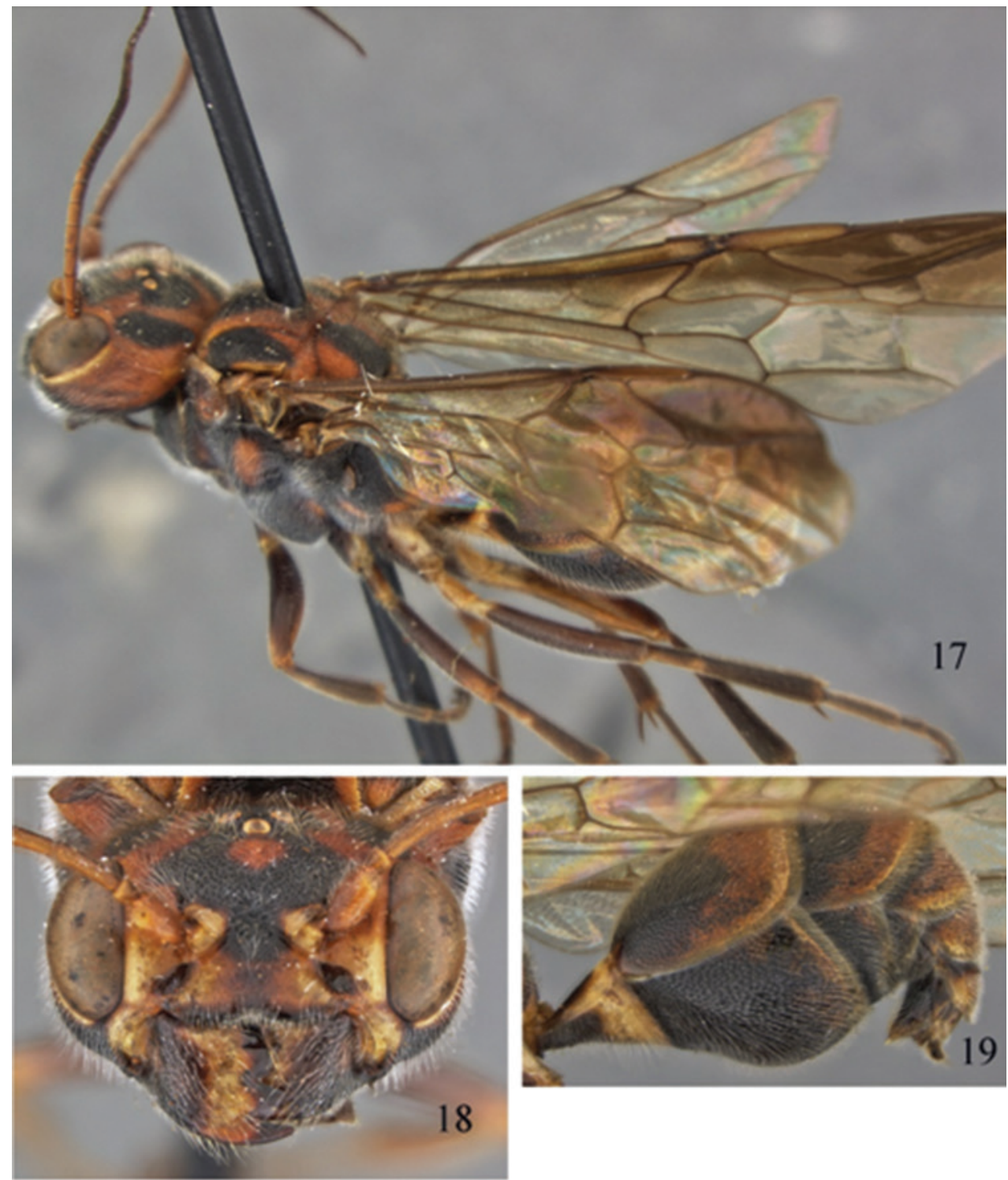

Figures I7-19. Taeniogonalos tricolor, female. 17 Lateral $18 \mathrm{Head}$, front 19 Metasoma, lateral.

Distribution. China, Thailand, Korea (Chen et al. 2014). Recorded from Thailand by Carmean and Kimsey (1998) and Chen et al. (2014), but no localities given. Chen et al. (2013) recorded 11 provinces in China but not Sichuan.

Comments. The largely reddish-brown color and lack of a medio-apical process on the second metasomal sternite will help separate this species. We examined only one specimen from Thailand, but the species seems widespread in Asia. 


\section{Taeniogonalos sp.1}

Figs 20-22

Specimen examined. THAILAND: Chiang Mai, Queen Sirit Botanic Garden, $18.881^{\circ} \mathrm{N}, 98.862^{\circ} \mathrm{E}, 811 \mathrm{~m}, \mathrm{MT}$, 28.iii-3.iv.2009, K. Kaewjanta \& R. Sawkord, H2614" (1 +, QSBG); Chiang Mai, Doi Phahompok NP, Mae Fang Hotspring, $569 \mathrm{~m}, 19^{\circ} 57.961^{\prime} \mathrm{N}, 99^{\circ} 9.356^{\prime} \mathrm{E}$, Mal. trap, 7-14.III.2008, P. Wongchai, leg. T6286 (1 9 , QSBG).

Comments. This is similar to T. sauteri but the metasoma is almost completely black and there is a distinct medio-apical process on the second sternite. This process is short and apically truncate. It does not key in Chen et al. (2014) and we do not have enough specimens to evaluate its status.

\section{Taeniogonalos sp.2}

Fig. 23

Specimen examined. THAILAND Nan, Doi Phu Kha NP Office 6, $19^{\circ} 12.349^{\prime} \mathrm{N}$, $101^{\circ} 4.617^{\prime} \mathrm{E}, 1360 \mathrm{~m}$, Malaise trap, 22-19.iii.2008, Charoen \& Nikorn leg., T3326” (1 Љ).

Comments. This may be male of the unidentified female above. The antenna has elongate tyloids on antennomeres 10-15.

\section{Trigonalys india Smith, sp. $\mathbf{n}$.}

http://zoobank.org/B7033A5B-6F42-43DF-A715-2A33DB4DC716

Figs 24-27

Trigonalys rufiventris: Carmean and Kimsey 1998: 70 (misidentification).

Description. Female. Length $8.0 \mathrm{~mm}$. Head black; clypeus and mandibles yellowish except apex of mandible black. Mesosoma black with yellow spot on dorsoposerior pronotum. Legs black with following yellow: apices of coxae, trochanters, extreme bases of femora, apical third of fore femur, outer surfaces of tibiae. Metasoma orange with first segment, and central area of sterna 2 and 3 black. Basal half of wings hyaline, somewhat darkly infuscated at center and apex; veins and stigma black. Head and body with silvery hairs. Head smooth, shiny with very few scattered fine punctures; mesosoma and metasoma uniformly finely punctate. Antenna long, filiform, with 25-26 antennomeres, $2 \times$ head width. Malar space narrow, slightly less than diameter of an ocellus. Eyes small, round, inner margins not converging below; lower interocular distance about $1.4 \times$ eye height. Lower frons between antennae shelflike or ledgelike, overhanging supraclypeal area. Distance between toruli about equal to distance be- 

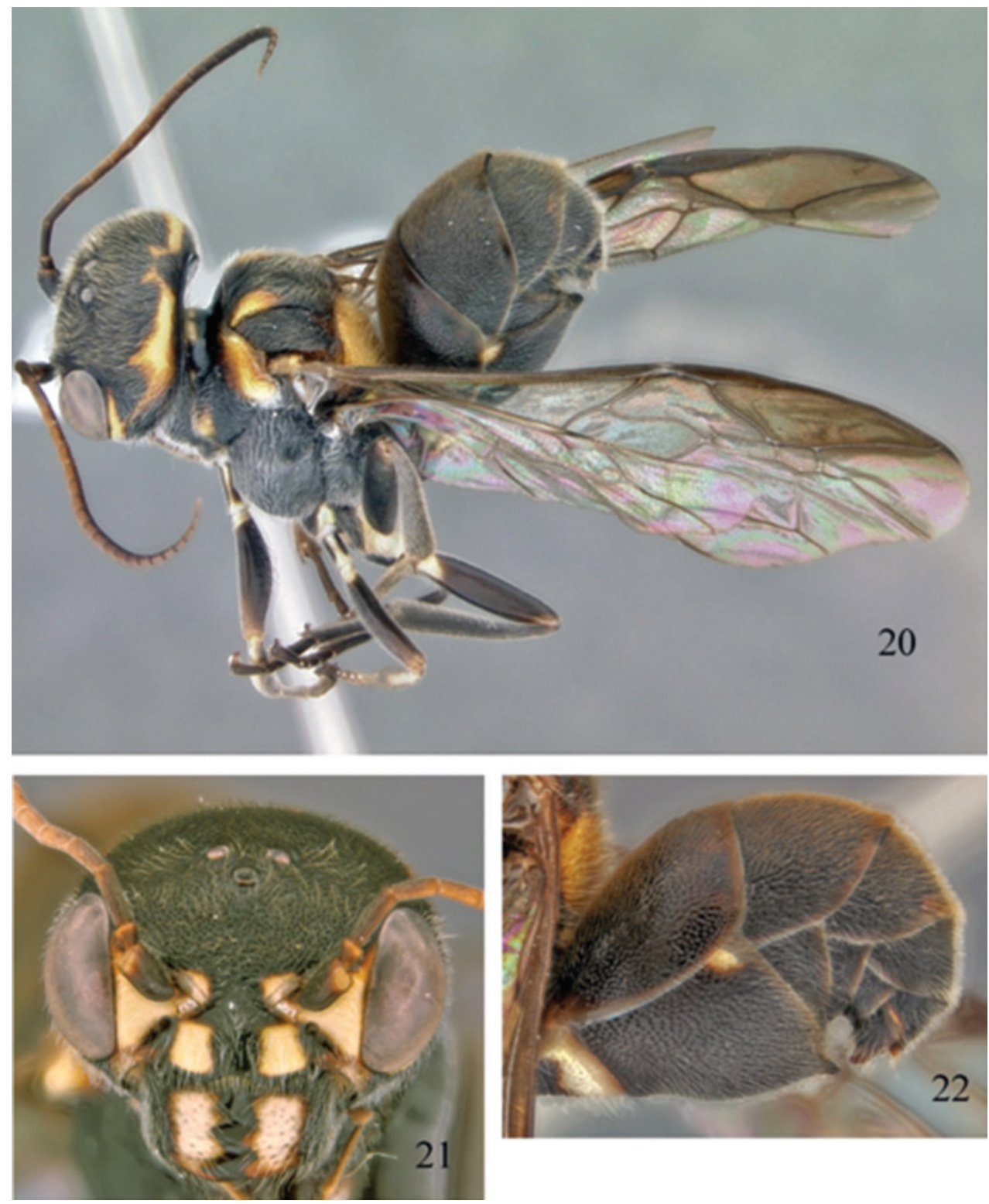

Figures 20-22. Taeniogonalos sp., female. 20 Lateral 21 Head, front 22 Metasoma, lateral.

tween torulus and inner margin of eye. Occipital carina narrow, less than half diameter of an ocellus. Medio-apical process at apex of sternite 3, flangelike, directed backward apically, quadrate.

Male. Length, $7.8 \mathrm{~mm}$. Color similar to female but metasoma mostly black, to darky reddish mostly at base of second tergite. Tyloids present on antennomeres 12-16, round, shiny, diminishing in size toward antennomere 16. 


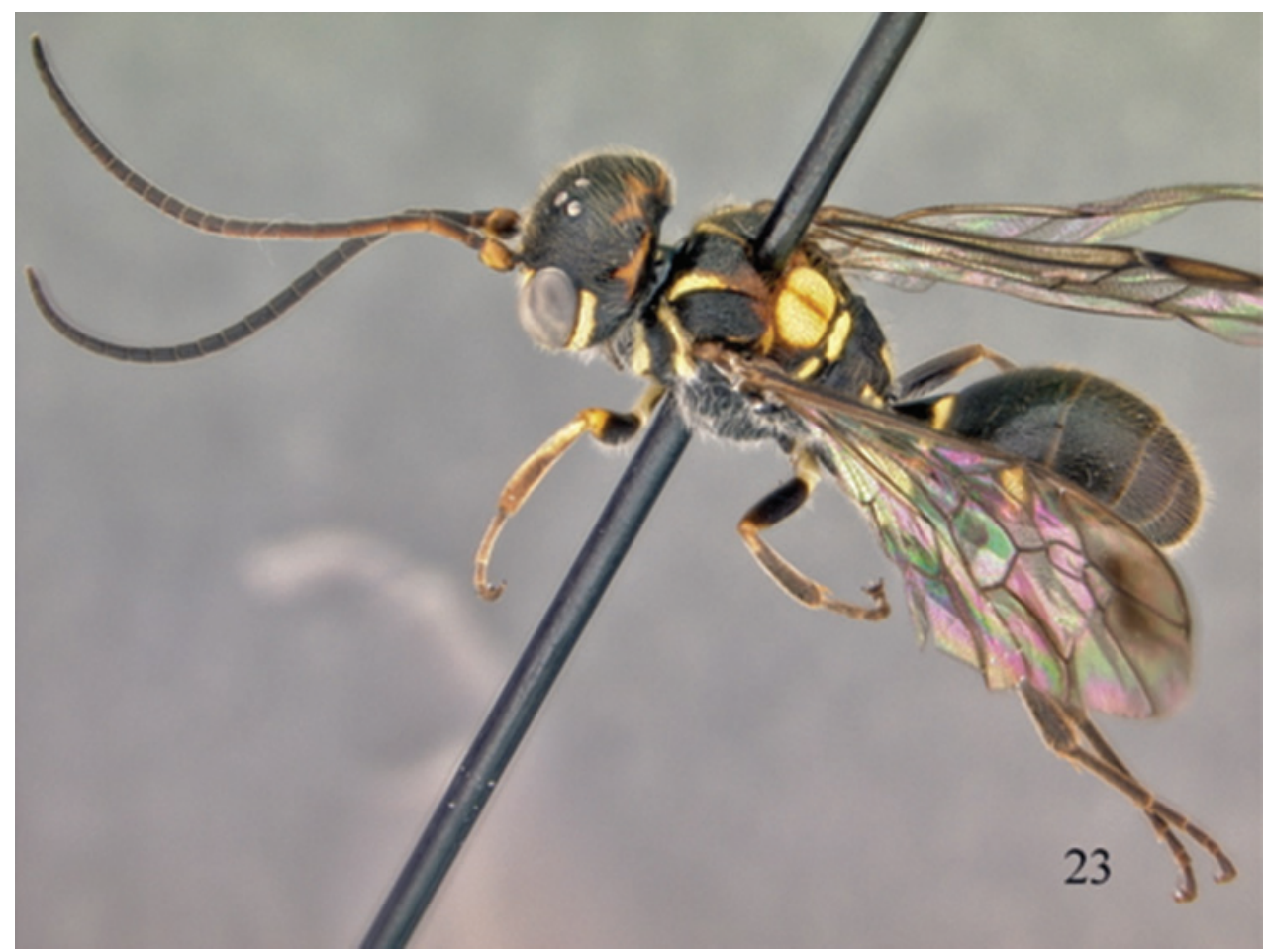

Figure 23. Taeniogonalos sp., male, dorsolateral.

Type material. Holotype, female, labeled "Nilgiri Hills, Singara, 3400', So. India, V-48, P. S. Nathan" (MCZ). Paratypes: Same data as for holotype (1 9, MCZ); Jabalpur, central India, Sep. 1957, 1600 ft., P. S. Nathan (1 ㅇ, 1 O, OSAC) (female with head missing).

Etymology. Named after the country of origin, a noun in apposition.

Comments. These are the specimens examined and identified as Trigonalys rufiventris (Magretti) by Carmean and Kimsey (1998). Generic characters place them in Trigonalys, and, although similar to L. rufiventris in color, they differ by the placement of the occipital carina, overhanging shelflike interantennal area, presence of tyloids on the antenna of the male, and a medio-apical process on the third sternite of the female.

Most species of Trigonalys are Neotropical and Ethiopian. Only one species is recorded from Asia, T. lachrynosa Westwood, 1874, described from Mindanao, Philippines. We have examined one female of T. lachrynosa from "Surigao, Mindanao" in the USNM, identical to Westwood's illustration (1874, plate 23, fig. 5), the same specimen examined by Carmean and Kimsey (1998). Trigonalys lachrynosa is almost entirely black with small yellow spots on the mesosoma. We know of no other species of Trigonalys with the color combination of $T$. india - the mostly black head, mesosoma, and legs and a mostly reddish metasoma. 

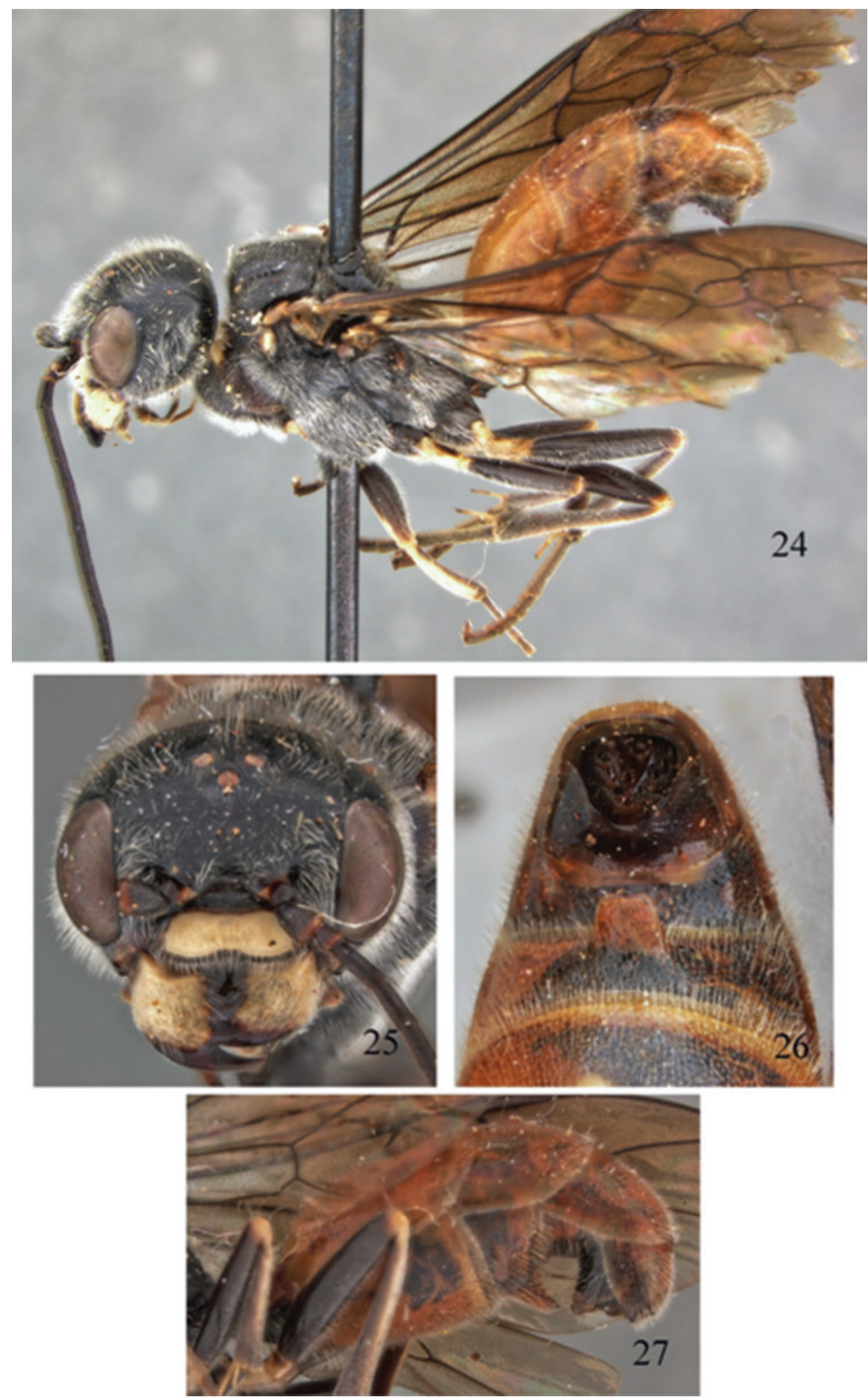

Figures 24-27. Trigonalys lindia, holotype female. 24 Lateral 25 Head, front $\mathbf{2 6}$ Apex of metasoma, ventral, showing projection on third sternite $\mathbf{2 7}$ Metasoma, lateral. 


\section{Acknowledgments}

We thank the following for loan of specimens: W. Srisuka (QSBG); James Hogan (OXUM); Christopher Marshall (OSAC); Philip Perkins (MCZ); Martin Schwarz (OLML); and John Huber (CNC). National Foundation Grant DEB-0542864, funded the Thailand Biodiversity Inventory. Thanks also to M. J. Sharkey and S. Clutts, University of Kentucky, Lexington, for sorting and sending Thai specimens. Michele Touchet, Systematic Entomology Laboratory, USDA, Washington, D.C. helped with the images.

\section{References}

Bischoff H (1913) Trigonaloiden aus Formosa. Archiv für Naturgeschichte 79: 150-156.

Bischoff H (1938) Trigonaloidae. Hymenopterorum Catalogus 5: 1-18.

Zaifu X, Huayan C, van Achterberg K, He J (2014) A revision of the Chinese Trigonalyidae

(Hymenoptera, Trigonalyoidea). ZooKeys 385: 1-207. doi: 10.3897/zookeys.385.6560

Chen SH (1949) Records of Chinese Trigonaloidae (Hymenoptera). Sinensia 20: 7-18.

Carmean D, Kimsey LS (1998) Phylogenetic revision of the parasitoid wasp family Trigonalidae

(Hymenoptera). Systematic Entomology 23: 35-76. doi: 10.1046/j.1365-3113.1998.00042.x

Magretti P (1897) Viaggio de Leonardo Fea in Birmania e regioni Vicine LXXIV. Imenotteri.

Parte seconda. Trigonalidi. Betilidi. Crisdidi colla descrizione di parecchie nouve specie.

Annali del Museo Civico di Storia Naturale di Genova (2) 17(37): 308-326.

Schulz WA (1908) Die Trigonaloiden des Genueser Naurhistorischen Museeums. Annali del Museo Civico di Storia Naturale di Genova (3) 4: 23-37.

Spinola MM (1840) G. Trigonalis. Trigonalis. Klug. Magasin de Zoologie 10: 1-20 (pl.5).

Strand E (1913) H. Sauter's Formosa-Ausbeute. Trigonalidae (Hym.). Separatabdruck aus Supplemmenta Entomologica 3: 32-33.

Weinstein P, Austin AD (1991) The host-relationships of Trigonalyid wasps (Hymenoptera: Trigonalyidae), with a review of their biology and catalogue to world species. Journal of Natural History 25: 398-433. doi: 10.1080/00222939100770281

Westwood J (1874) Thesaurus Entomologicus Oxoniensis. Clarenden Press, Oxford, 205 pp., 40 pls. 